\title{
NATURAL DURABILITY AND PERFORMANCE OF HORNBEAM CEMENT BONDED PARTICLEBOARD
}

\author{
Antonios N. Papadopoulos \\ Technological Educational Institute of Kavala, Branch of Drama, Department of Forestry and Management \\ of Natural Environment, Laboratory of Wood and Wood Products, TK 66100, Drama, Greece.
}

Corresponding author: antpap@teikav.edu.gr

Received: 07.11 2007. Accepted: 08.04. 2008.

\begin{abstract}
Cement bonded particleboards were manufactured from hornbeam (Carpinus betulus L.) wood particles. Hydration tests were carried out to determine the inhibitory index in order to characterise wood-cement compatibility. The results revealed that the mixture of hornbeam -cement can be classified as moderate inhibition. Two wood: cement ratios were applied in this study, namely 1:3 and 1:4, for the board manufacture. It was found that an increase of cement-wood ratio resulted to an increase in all, but MOR values. All properties of the boards made from 1:4 wood: cement ratio, surpassed the minimum requirements set forth by the building type $\mathrm{HZ}$ code. Boards were exposed to brown and white rot fungi, Coniophora puteana, Trametes versicolor respectively. Overall, both fungi failed to attack the cement-bonded boards.
\end{abstract}

Keywords: cement, hornbeam, Carpinus betulus L, Coniophora puteana, Trametes versicolor

\section{INTRODUCTION}

Cement-bonded particleboard has been manufactured using conventional technology, where the boards are kept under pressure for consolidation for several hours. The pressure is necessary because the hydration of the cement is a slow process. The cement hardening is usually completed in three to four weeks. The characteristics that make such type of boards desirable to various construction applications are decay and fire resistance and good dimensional stability.

A significant problem however, when these products are manufactured, is the compatibility of wood with cement. The term compatibility, when applied in the area of wood-cement composites, refers to the degree of cement setting after mixing with water and with a given wood in fragmented form. Generally, if the chemical process of cement hardening is undisturbed by the presence of wood, it is considered that cement and wood are compatible. On the other hand, if cement hardening is impaired by the presence of wood, then cement and wood are referred as incompatible (Jorge et al. 2004). The latter is commonly expressed by a lowering of the physical and mechanical properties of the final product. Weatherwax and Tarkow (1964), described a method to quantify differences among species by using the term inhibitory index, which compares the extension of wood-cement inhibition based on the percentage increase in setting time. Hofstrand et al. (1984), incorporated maximum temperature and the maximum slope of the temperature curve of the wood-cement mixture and neat cement, respectively, into the inhibitory index calculations. The inhibitory index of any species can be computed from the values of maximum temperature of hydration, the maximum slope of the exothermic curve and the hydration time needed to reach maximum temperature of the inhibited cement when compared respectively with the values of the uninhibited cement. The lower the inhibitory index, the higher the compatibility between cement and wood. The objective of this communication was to manufacture wood cement particleboards using particles of hornbeam and to evaluate the physico-mechanical properties and decay resistance of the boards. 


\section{Hydration test}

\section{MATERIALS AND METHODS}

A wide range of wood species have been used in wood-cement composite manufacture, including both temperate and tropical woods. The study reported herein utilised sapwood from hornbeam wood (Carpinus betulus L.). The hydration test method used was the same as described by Hofstrand et al.(1984) and recently applied by Okino et al. (2004, 2005). Wood particles were ground in a mill and screened in sieves of $-20+42$ mesh. Type I commercial Portland cement was used. Distilled water $(90.5 \mathrm{ml})$ was added to a mixture of cement $(200 \mathrm{~g})$ and wood $(15 \mathrm{~g}$ oven-dry basis) in a polyethylene bag for 3 minutes. The amount of water added was based on experiments reported by Weatherwax and Tarkow (1964) suggested the use of $2.7 \mathrm{ml}$ of water per gram of ground-wood (adjusted to oven-dry basis) and additional $0.25 \mathrm{ml}$ of water per gram of cement. The cement-wood-water mixture was placed in a wide-mouth insulated flask with a thermocouple wire and then covered with styrofoam. The flask was sealed with wrapping tape. The temperature of the mixture was measured and plotted against time. The time to attain maximum temperature was considered to be the required setting time of the mixture. Two replications were applied to each species of wood-water-cement mixtures and neat cement. All the experiments were carried out at room temperature.

To calculate the inhibitory index $(l)$ of the species, the following equation was used:

$$
1=100\left[\left(\left(\mathrm{t}_{2}-\mathrm{t}_{2}{ }_{2}\right) / \mathrm{t}_{2}{ }_{2}\right) *\left(\left(\mathrm{~T}_{2}{ }_{2}-\mathrm{T}_{2}\right) / \mathrm{T}_{2}{ }_{2}\right) *\left(\left(\mathrm{~S}_{2}{ }_{2}-\mathrm{S}_{2}\right) / \mathrm{S}_{2}{ }_{2}\right)\right]
$$

where

$t_{2}$ : time to reach maximum temperature of the inhibited cement (wood-cement-water mixture)

$\mathrm{t}_{2}$ : time to reach maximum temperature of the uninhibited cement (cement -water mixture)

$\mathrm{T}_{2}$ : maximum hydration temperature of the inhibited cement (wood-cement-water mixture)

$\mathrm{T}_{2}$ : maximum hydration temperature of the uninhibited cement (cement -water mixture)

$\mathrm{S}_{2}$ : maximum temperature-time slope of inhibited cement (wood-cement-water mixture)

$\mathrm{S}_{2}$ : maximum temperature-time slope of uninhibited cement (cement-water mixture)

\section{Board manufacture}

Hornbeam particles that previously passed the $1 \mathrm{X} 1 \mathrm{~mm}$ sieve were the raw material used in this study. The bonding agent employed was commercial grade Portland cement, type I. The wood: cement ratios applied in this study were 1:3 and 1:4, based on the oven dry weight. Calcium chloride $\left(\mathrm{CaCl}_{2}-3 \%\right.$ based on weight of cement) was introduced into cement slurry to accelerate cement set during hydration. The boards manufactured according to methodology described in Okino et al. (2004) and Fuwape (1995). A predetermined amount of air-dried wood particles and a $\mathrm{CaCl}_{2}$ distilled water solution were thoroughly blended. Cement was subsequently added and the constituents were mixed until the cement paste completely hydrated. The quantity of distilled water added, was calculated using a relationship applied by other researchers as well (Fuwape 1995; Moslemi and Pfister 1987; Sudin et al. 1995). In his formulation, the water requirement was determined as follows:

$$
\text { water }(\text { litres })=0.35 \mathrm{C}+(0.30-\mathrm{MC}) \mathrm{W}
$$

where:

$$
\begin{aligned}
& \mathrm{C}=\text { cement weight }(\mathrm{kg}) \\
& \mathrm{MC}=\text { wood strands moisture content (oven-dry basis) } \\
& \mathrm{W}=\text { oven-dry wood strand weight }(\mathrm{kg}) .
\end{aligned}
$$


After 15 minutes of manual mixing, the cement-wood water mixture was screened onto to a caul. The mat was evenly distributed to provide as uniform a density as possible and pre-pressed to a thickness of approximately $50 \mathrm{~mm}$. Cold pressing took place under an initial pressure of $5 \mathrm{MPa}$, to a $15 \mathrm{~mm}$ thickness, after which the board was retained in compression for 24 hours. Target board density was $1.2 \mathrm{~g} / \mathrm{cm}^{3}$. A total of six boards were made. Boards with pure cement were not manufactured. To minimize cement capillary desiccation and enhance hydration, boards were misted with distilled water, then wrapped in cellophane before storing for curing at $20^{\circ} \mathrm{C}$ and $65 \%$ relative humidity for a month. After manufacturing, the boards were conditioned at $20^{\circ} \mathrm{C}$ and $60 \%$ relative humidity and tested for IB (internal bond), MOR -MOE (moduli of rupture and elasticity), TS (thickness swelling, after 24 hours immersion in water) according to procedures defined in the European Union standards EN 310, EN 317 and EN 319.

\section{Decay tests}

Samples were packed in an argon atmosphere and sterilised by irradiation, (2.5 Mrad.) prior to decay tests, using the methods described in DD ENV 12038: 1996. The irradiation sterilisation access the whole sample, since its thickness $(15 \mathrm{~mm})$ is very low. Laboratory pure strains of the brown rot fungi Coniophora puteana (No FPRL 11E) and white rot fungi Trametes versicolor (CTB 863A) were used, grown on malt agar. Blocks were planted on sterile specimen supports placed on the cultures of the test fungus actively growing on 5\% malt agar in $500 \mathrm{ml}$ capacity jars. An additional set of sterile control samples were used to assess operational control losses. The closed jars were incubated for 16 weeks, at $22+/-1^{\circ} \mathrm{C}$ and $75+/-5 \%$ relative humidity to evaluate the efficacy of the treatments. After incubation, the samples were removed from the jars, cleaned, weighed, conditioned to constant weight as above and re-weighed. Weight loss (WL) was expressed as a percentage of the initial weight of the sample. Weight losses from sterile controls were subtracted from the decay results to give corrected data.

\section{RESULTS AND DISCUSSION}

\section{Hydration test}

The results obtained from the hydration test are shown in Table 1. From this it can be seen that the mixture of hornbeam-cement was classified as moderate inhibition. When $\mathrm{CaCl}_{2}$ was incorporated, the mixture was graded as low inhibition. The value of inhibitory index is negative, probably due to the capacity of the $\mathrm{CaCl}_{2}$ to buffer or minimize the adverse effect of the soluble sugars and extractives and also to accelerate the cement hardening and setting. Comparable data in the literature as far as the inhibition index between hornbeam particles and cement mixture did not exist. Other wood species that in mixture with cement gave moderate inhibition and therefore similar inhibition index are eucalyptus (Okino et al. 2004), cypress (Okino et al. 2005) and pseudoacacia (Semple and Evans, 1998).

Table 1 Inhibitory index of hornbeam wood species used in this study.

(Standard deviations in parentheses).

\begin{tabular}{|c|c|c|}
\hline Wood species & \multicolumn{2}{|c|}{ Inhibitory index (\%) } \\
\hline & With out additive & With additive $\left(3 \% \mathrm{CaCI}_{2}\right)$ \\
\hline Hornbeam & $39.15^{\mathrm{a}}(4.3)$ & $-0.92(0.08)$ \\
\hline
\end{tabular}

a: Each value represents the mean of four replicates 


\section{Mechanical and physical properties}

The mechanical and physical properties of the boards are presented in Table 2. Table 2 shows that an increase of cement-wood ratio resulted to an increase in all, but MOR values. This is in line with the observations made by Moslemi and Pfister (1984) and Papadopoulos et al (2006). They found that the modulus of elasticity, internal bond strength and thickness swell increased linearly with greater cementwood ratio. The relationship between cement-wood ratio and MOR values is considerably different that of MOE or IBS or TS. The MOR values are decreased with an increase of cement-wood ratio. The higher proportion of wood in the board may enhance the flexural property of the board. When wood occupies more volume in the board, the areas of stress concentration around the component particles are more diffused, resulting in increased to applied stresses (Fuwape, 1984). The results reported here in are in conformity with those made by other workers (Moslemi and Pfister 1984; Sudin et al. 1995; Papadopoulos et al. 2006) regarding the use of cement in particleboard, flakeboard and OSB manufacture. All properties of the boards, if we exclude the IB value of boards made from 1:3 wood: cement ratio, surpassed the minimum requirements set forth by the building type $\mathrm{HZ}$ code, as shown in the last line of the Table 2. This is in line with the results published by Okino et al (2005). They manufactured cement bonded boards with 1:3 wood: cement ratio and used cypress particles.

Table 2. Mechanical and physical properties of cement-bonded hornbeam boards.

(Standard deviations in parentheses).

\begin{tabular}{|l|c|c|c|c|c|}
\hline Wood: Cement & Density $^{\mathbf{a}}\left(\mathbf{g} / \mathbf{c m}^{\mathbf{3}}\right)$ & $\mathbf{M O R}^{\mathbf{b}} \mathbf{( N / \mathbf { m m } ^ { 2 } )}$ & $\mathbf{M O E}^{\mathbf{b}} \mathbf{( N / \mathbf { m m } ^ { 2 } )}$ & $\mathbf{I B}^{\text {a }} \mathbf{( N / \mathbf { m m } ^ { 2 } )}$ & $\mathbf{T S}^{\mathbf{a}} \mathbf{( \% )}$ \\
\hline $1: 3$ & $1.27(0.18)$ & $12.68(0.5)$ & $6009.6(32.1)$ & $0.35(0.07)$ & $1.75(0.6)$ \\
\hline $1: 4$ & $1.28(0.12)$ & $10.56(0.8)$ & $7056.4(199.3)$ & $0.56(0.04)$ & $0.67(0.1)$ \\
\hline BISON type HZ & 1.20 & 9.0 & 3000 & 0.40 & $1.2-1.8$ \\
\hline
\end{tabular}

a: Each value represents the mean of twelve replicates

b: Each value represents the mean of eight replicates

\section{Decay resistance}

The results obtained after a 16-week incubation period are presented in Table 3. Overall, both fungi failed to attack the cement-bonded boards. Visual examination revealed a slight presence of mycelium in the surface of the tested samples. Boards showed weight gain instead of weight loss. This according to Okino et al. $(2004,2005)$ was a consequence of the final curing process of the cement, at this high cement: wood ratios. Investigation of cement bonded panels is not very common. Tests conducted by Dinwoodie and Paxton (1991) and Pirie et al. (1990) suggested that conventionally made cement bonded particleboards are very resistant to the attack of the white rot fungus Pleurotus ostreatus and to the brown rot fungus Coniophra puteana. Similar results were also reported by Okino et al. (2005) in cement bonded boards made cypress particles. The present study was the first study, as far as the authors are aware, that examined the decay resistance of oriented strand board using cement as a binder. 
Table 3. Weight loss (WL) of cement-bonded hornbeam boards. (Standard deviations in parentheses).

\begin{tabular}{|l|c|c|}
\hline & Brown rot & White rot \\
\hline Wood: Cement & WL $^{\mathbf{a}} \mathbf{( \% )}$ & WL $^{\mathbf{a}}(\mathbf{\%})$ \\
\hline $1: 3$ & $0.85(0.07)$ & $-1.88(0.40)$ \\
\hline $1: 4$ & $-2.92(0.20)$ & $-1.45(0.66)$ \\
\hline
\end{tabular}

a: Each value represents the mean of twelve replicates

\section{CONCLUSIONS}

The aim of this paper was to manufacture wood cement particleboards using particles of hornbeam and to evaluate the physico-mechanical properties and decay resistance of the boards. Based on hydration tests, it was found that the mixture of maple-cement can be classified as moderate inhibition. Two wood: cement ratios were applied in this study, namely $1: 3$ and 1:4, for the board manufacture. It was found that an increase of cement-wood ratio resulted to an increase in all, but MOR values. All properties of the boards made from 1:4 wood: cement ratio, surpassed the minimum requirements set forth by the building type $\mathrm{HZ}$ code. Boards were exposed to brown and white rot fungi, Coniophora puteana, Trametes versicolor respectively. Overall, both fungi failed to attack the cement-bonded boards.

\section{REFERENCES}

BISON. 1978. Wood-Cement Board. Report. British Research Establishement (Bre). Uk. Pp. 1-65.

DD ENV 12038: 1996. Durability of wood and wood - based products. Wood based panels. Method of test for determining the resistance against. Wood - destroying basidiomycetes. DD ENV 12038: 1996. $36 \mathrm{p}$.

Dinwoodie, J.M.; Paxton, B.H. 1991. The long term performance of cement-bonded particleboard. In: Inorganic bonded wood and fiber materials. $2^{\text {nd }}$ International Conference, Moscow, pp 45.

European Committee for Standardisation (CEN). 1993. Particleboards and fibreboards-Determination of modulus of elasticity in bending and of bending strength. European Standard EN 310.

European Committee for Standardisation (CEN). 1993. Particleboards and fibreboards-Determination of swelling in thickness after immersion in water. European Standard EN 317.

European Committee for Standardisation. (CEN) 1993. Particleboards and fibreboards-Determination of tensile strength perpendicular to the plane of the board. European Standard EN 319.

Fuwape, J.A. 1995. The effect of cement-wood ratio on the strength properties of cement-bonded particleboard from spruce. Journal of Tropical Forest Products 1:49-58. 
Hosfstrand, A.D.; Moslemi, A.A.; Garcia, J.F. 1984. Curing characteristics of wood particles from nine northern Rocky Mountain species mixed with Portland cement . Forest Products Journal 34(2): $57-61$.

Jorge, F.C.; Pereira, C.; Ferreira, J.M.F. 2004. Wood-cement composites: a review. Holz als Rohund Werkstoff 62: 370-377.

Moslemi, A.A.; Pfister, S.C. 1987. The influence of cement-wood ratio and cement type on bending strength and dimensional stability of wood-cement composite panels. Wood and Fiber Science 19:165175.

Okino, E.Y.A.; De Souza, M.R.; Santana, M.A.E.; Da Alves, M.V.; De Souza, M.E.; Texeira, D.E. 2004. Cement-bonded wood particleboard with a mixture of eucalypt and rubberwood. Cement \& Concretes Composites 26:729-734.

Okino, E.Y.A.; De Souza, M.R.; Santana, M.A.E.; Da Alves, M.V.; De Souza, M.E.; Texeira, D.E. 2005. Physicomechanical properties and decay resistance of Cupressus ssp. cement-bonded particleboards. Cement \& Concretes Composites 27:333-338.

Papadopoulos, A.N.; Ntalos, G.A.; Kakaras, I. 2006. Mechanical and physical properties of cementbonded OSB. Holz als Roh-und Werkstoff 64:517-518.

Pirie, B.J.; Glasser, F.O.; Schimitts, H.; Akers, S.A.S. 1990. Durability studies and characterisation of the matrix and fibre-cement interface of asbestos-free fibre-cement products. Cement \& Concrete Composites 12:233-234.

Semple, K.E.; Evans, P.D. 1998. Compatibility of some Australian acacias with Portland cement. Holz als Roh-und Werkstoff 56(1):24.

Sudin, R.; Shaari, K.; Selamat, S. 1995. Cement-bonded particleboard from pre-soaked oil palm trunk: effects of particle size and chemical additive. Journal of Tropical Forest Products 1:71-77.

Weatherwax, R.C. ; Tarkow, H. 1964. Effect of wood on setting of Portland cement. Forest Products Journal 12: 567-570. 